\title{
Clinical Reasoning: A case of COVID- 19-associated pharyngeal-cervical-brachial variant of Guillain-Barré syndrome
}

Giuseppe Liberatore, MD, Tiziana De Santis, MD, Pietro Emiliano Doneddu, MD, Francesco Gentile, MD, Alberto Albanese, MD, PhD, and Eduardo Nobile-Orazio, MD, PhD, FAAN

Neurology ${ }^{\circledR}$ 2020;95:978-983. doi:10.1212/WNL.0000000000010817

\section{Section 1}

In March 2020, a 49-year-old man was admitted through our emergency department due to a 1week history of fever $\left(39-40^{\circ} \mathrm{C}\right)$ and cough. His medical history included arterial hypertension and a testicular seminoma in 2011 treated with surgery and platinum-based chemotherapy. Laboratory tests revealed increased C-reactive protein, mild lymphopenia, and thrombocytopenia. Chest CT showed multifocal ground-glass opacities and nasopharyngeal swab was positive for severe acute respiratory syndrome coronavirus 2 (SARS-CoV-2), leading to a diagnosis of coronavirus disease 2019 (COVID-19). The patient was hospitalized and treatment with hydroxychloroquine, lopinavir/ritonavir, and ceftriaxone was started.

Four days later, the patient's respiratory function rapidly worsened, requiring transfer to the intensive care unit (ICU) and mechanical ventilation (MV). Despite early clinical stabilization, attempts of weaning from ventilator failed due to persistence of respiratory failure. During the ICU stay, anesthesiologists reported unusual symptoms, such as gastroparesis, alternating episodes of tachy-/bradyarrhythmia, and frequent hypertensive crises. Twenty-three days after ICU admission, respiratory function improved. Upon reversal of sedation, the patient was profoundly asthenic and since a generalized flaccid weakness was noted, he was transferred to our neurology department.

\author{
Correspondence \\ Dr. Liberatore \\ giuseppe.liberatore@ \\ humanitas.it
}

MORE ONLINE

COVID-19 Resources

For the latest articles, invited commentaries, and blogs from physicians around the world

NPub.org/COVID19

On neurologic examination, the patient was alert and oriented and showed dysphonia, dysphagia, left VII and right XII cranial nerve palsy, and weakness of the neck flexors and proximal and distal muscles of the upper limbs in a symmetrical distribution (Medical Research Council 3/5), with diffuse hypotonia and muscle hypotrophy. Strength in the lower limbs was normal except for a mild weakness $(4 / 5)$ of the extensor hallucis longus bilaterally. There was diffuse hyporeflexia in the 4 limbs. Decreased vibratory sensation in the ankles was detected. Gait and coordination were normal. Persistent sinus tachycardia was noted.

\section{Questions for consideration:}

1. What is the differential diagnosis for the patient's neurologic symptoms and signs?

2. Could this clinical picture be a COVID-19-related neurologic manifestation?

3. Which investigations would be appropriate for diagnostic workup?

\section{GO TO SECTION 2}

\footnotetext{
From the Neuromuscular and Neuroimmunology Service (G.L., P.E.D., F.G., E.N.-O.) and Department of Neurology (T.D.S., A.A.), IRCCS Humanitas Clinical and Research Institute, Rozzano; Department of Neuroscience (A.A.), Catholic University of the Sacred Heart, Milan; and Department of Medical Biotechnology and Translational Medicine (E.N.-O.), Milan University, Italy.

Go to Neurology.org/N for full disclosures. Funding information and disclosures deemed relevant by the authors, if any, are provided at the end of the article.
} 


\section{Section 2}

In the ICU setting, neurologic complications are common and include encephalopathy, seizures, stroke, and neuromuscular disorders. In our patient, the acute/subacute onset of symmetric weakness in the upper limbs with flaccid tone, reduced tendon reflexes, and respiratory insufficiency should raise the suspicion of a neuromuscular disorder, such as myopathy, myasthenia gravis, critical illness polyneuropathy and myopathy (CIP/CIM), or Guillain-Barré syndrome (GBS) and its variants. An underlying disorder of the CNS, such as stroke, neuroinflammatory disease, CNS infection, paraneoplastic syndrome, or a spine lesion, is less likely but should also be taken into account.

Since December 2019, SARS-CoV-2 infection has spread rapidly from China to a pandemic level causing great health care concern worldwide. Its associated disease, COVID-19, mostly affects the respiratory system, ranging from mild flu-like symptoms to severe pneumonia. There is growing evidence of neurologic manifestations in COVID-19, including febrile seizures, headache, dizziness, myalgia, encephalopathy/encephalitis, stroke, and acute peripheral nerve diseases. ${ }^{1} \mathrm{~A}$ few cases of $\mathrm{GBS}^{2-6}$ in patients with COVID-19 have been reported, with either a demyelinating or an axonal pattern. A potential unmasking of a myasthenic syndrome during the course of the infection should also be considered.

Institution of proper diagnostic workup is essential and includes neurophysiologic studies, CSF analysis, antiganglioside and anti-acetylcholine receptor (AChR) antibodies testing, and imaging of brain and spinal cord and plexuses. A total body CT scan may be performed in case of a suspected paraneoplastic etiology.

CSF test showed normal glucose levels $(62 \mathrm{mg} / \mathrm{dL}$; normal $60-80 \mathrm{mg} / \mathrm{dL}$ ), mild hyperproteinorrachia $(48 \mathrm{mg} / \mathrm{dL}$; normal $15-45 \mathrm{mg} / \mathrm{dL}$ ), and no cells. CSF viral PCR for herpesviruses as well as SARS-CoV-2 resulted negative. Cytology was negative for malignancies. Neurophysiologic studies (table) showed reduced distal compound muscle action potential amplitudes in the peroneal nerve bilaterally, with normal conduction velocities and motor distal latencies.

Table Results of motor nerve conduction study

\begin{tabular}{|c|c|c|c|c|c|}
\hline Motor nerves & Onset latency, ms & Amplitude, mV & Duration, $\mathrm{mV} * \mathrm{~ms}$ & MCV, m/s & F-wave, ms \\
\hline \multicolumn{6}{|l|}{ Median nerve, right } \\
\hline Wrist-abductor pollicis brevis & 3.42 & 7.1 & 9.2 & & \\
\hline Elbow-wrist & 8.06 & 7.2 & 9.4 & 53.9 & \\
\hline \multicolumn{6}{|l|}{ Peroneal nerve, left } \\
\hline Ankle-extensor digitorum brevis & 5.82 & 0.41 & 9.2 & & \\
\hline Below fibula-ankle & 12.9 & 0.35 & 9.5 & 41.0 & \\
\hline Above fibula-below fibula & 15.5 & 0.39 & 9.0 & 46.2 & \\
\hline \multicolumn{6}{|l|}{ Peroneal nerve, right } \\
\hline Ankle-extensor digitorum brevis & 4.72 & 0.98 & 9.0 & & \\
\hline Below fibula-ankle & 12.1 & 1.19 & 11.2 & 43.4 & \\
\hline Above fibula-below fibula & 14.3 & 1.20 & 10.3 & 50.0 & \\
\hline \multicolumn{6}{|l|}{ Tibial nerve, left } \\
\hline Medial malleolus-abductor hallucis brevis & 3.40 & 9.5 & 9.3 & & 54.5 \\
\hline Popliteal fossa-medial malleolus & 12.5 & 5.9 & 10.4 & 44.0 & \\
\hline \multicolumn{6}{|l|}{ Tibial nerve, right } \\
\hline Medial malleolus-abductor hallucis brevis & 2.78 & 8.1 & 10.3 & & 53 \\
\hline Popliteal fossa-medial malleolus & 13.0 & 4.8 & 17.3 & 45.0 & \\
\hline \multicolumn{6}{|l|}{ Ulnar nerve, right } \\
\hline Wrist-abductor digiti minimi & 2.20 & 7.3 & 11.0 & & 30.8 \\
\hline Below elbow-wrist & 6.20 & 6.3 & 11.9 & 55.0 & \\
\hline
\end{tabular}

Abbreviation: $\mathrm{MCV}=$ motor conduction velocities. 
Motor and sensory parameters of the median, ulnar, tibial, and sural nerves were normal, as well as $\mathrm{F}$ waves of the tibial and ulnar nerves. Repetitive nerve stimulation at right ulnar and accessory nerve was negative. Needle EMG showed fibrillation potentials and positive sharp waves together with a reduced recruitment pattern in the deltoid, trapezium, biceps brachii, triceps brachii, and first interosseous muscles bilaterally.

Antiganglioside (immunoglobulin G anti-GM1, GM2, GD1a, GD1b, GT1a, GT1b, GQ1b) and AChR antibodies were not detected. Autoimmune serologic screening was negative, as well as repeated dosages of creatine kinase. Contrast-enhanced MRI of brain, cervical spine, and brachial plexus was negative. A total body CT scan excluded the presence of an oncologic disease. A follow-up electrophysiologic study was performed 14 days later, overlapping with the previous one.

\section{Question for consideration:}

1. Considering the results of the instrumental and laboratory tests, how would you refine your differential diagnosis?

GO TO SECTION 3 


\section{Section 3}

The following differential diagnoses were considered:

1. GBS: an acute inflammatory polyneuropathy characterized by acute/subacute motor weakness, hypo-/areflexia, and mild to moderate sensory impairment. Cranial nerve and autonomic involvement may be present in a subset of cases. Antecedent infections may be potential triggers, preceding neurologic symptoms by $2-3$ weeks. ${ }^{7}$

2. CIP/CIM: the most frequent neuromuscular disorder occurring in ICU, detected in up to half of critically ill patients. ${ }^{8}$ It usually presents as a distal axonal sensorymotor polyneuropathy affecting limbs and respiratory muscles, and it is usually suspected upon failure of weaning the patient from the ventilator when other causes have been excluded.

In our patient, the presence of a cranial nerve palsy, the distribution of weakness in the neck flexor muscles and in the upper limbs with a sparing of the lower limbs, and the presence of autonomic symptoms (gastroparesis, alternating episodes of tachy-/bradyarrhythmia, and frequent hypertensive crises) suggest a GBS diagnosis rather than CIP/ CIM. The Brighton Collaboration level 1 criteria were met. ${ }^{7}$ In CIP/CIM, cranial nerves and autonomic system are typically not involved, while sensory impairment is very frequent; prognosis is often poor, requiring postdischarge rehabilitation for several months in order to improve functional independence.

Considering that the clinical picture and the neurophysiologic examination were supportive for a diagnosis of an acute motor axonal neuropathy, ${ }^{9}$ the patient was diagnosed with pharyngealcervical-brachial (PCB) variant of GBS. Miller Fisher syndrome was excluded due to the absence of ophthalmoplegia, ataxia, and anti-GQ1b antibodies.

\section{Question for consideration:}

1. Which is the mainstay treatment and disease course in GBS?

GO TO SECTION 4 


\section{Section 4}

Rapid institution of high-dose IV immunoglobulin (IVIg) is warranted to halt GBS progression and favor clinical outcome. Nonetheless, the disease follows a monophasic course and spontaneous recovery in the absence of treatment may be observed.

In our case, during the first days of admission in our department (after 40 days from fever onset), the patient showed a spontaneous improvement of the clinical picture, thus treatment with IVIg was not performed. In the following 15 days, the patient showed an improvement of dysphagia and weakness of the upper limbs, and at discharge (at day 56 after admission) only mild weakness of the deltoid bilaterally and left biceps was evident.

\section{Discussion}

At the time of writing this article, about 20 cases of GBS associated with COVID-19 infection have been reported, encompassing several of its clinical variants, such as acute inflammatory demyelinating polyneuropathy, acute motor/ motor-sensory axonal neuropathy, Miller Fisher syndrome, polyneuritis cranialis, and facial diplegia. Almost $50 \%$ of these patients required $\mathrm{MV}$ and $10 \%$ of them died, suggesting that GBS associated with COVID-19 is more severe than GBS related to other etiologies, although excellent recovery after therapy is reported. ${ }^{6}$ It is possible that the neuromuscular dysventilation caused by GBS adds to the COVID-19-related respiratory dysfunction, resulting in a more severe clinical presentation. The clinical course in our patient is similar to what is described in previous cases, requiring ICU admission and MV, but after the acute phase our patient showed good spontaneous improvement. Because the patient was not treated with any immunotherapy, we had the opportunity to observe the natural evolution of the disease, confirming the possibility of a good prognosis despite poor clinical condition in the acute phase.

We report the first case of PCB variant of GBS associated with SARS-CoV-2 infection. PCB is considered a rare regional axonal variant of GBS (about 3\% of GBS cases ${ }^{10}$ ). Clinical features include oropharyngeal, neck, and arm weakness associated with arm areflexia. ${ }^{10}$ Lower limb weakness may also be present in variable degrees, although should never be more prominent than weakness in the other districts. Reflexes in the lower limbs are typically preserved in PCB, but in our patient the hyporeflexia and mild vibration deficits may be explained by considering the platinum-based chemotherapy performed in past years. Autonomic dysfunction in PCB may occur in up to $20 \%$ of cases. Differential diagnoses include Miller Fisher syndrome, myasthenia gravis, botulism, diphtheria, and brainstem stroke. Anti-GT1a IgG antibodies are a specific serologic marker for PCB, being positive in about 50\% of patients. CSF albumin-cytologic dissociation can be present in about
$40 \%-50 \%$ of patients. An antecedent upper respiratory tract infection rather than diarrhea is usually reported. ${ }^{10}$

As to the pathogenic relation with COVID-19 infection, the possible mechanism could be an aberrant immune response rather than a direct viral injury, considering the time interval between the onset of the antecedent illness and the onset of the neurologic symptoms (10-15 days), the lack of cells in the CSF, and the negativity of the PCR for SARS-Cov-2 in the CSF.

Our case adds to the evidence that rare neurologic manifestations are possible during COVID-19 infection. GBS associated with COVID-19 infection seems more severe than that related to other etiologies and our case expands the clinical spectrum of this specific putative condition. More data are needed to confirm the pathogenic link between COVID-19 and GBS to explain the occurrence of relatively higher percentages of axonal forms and to clarify the prognosis of these cases.

\section{Study funding}

There was no funding for this study.

\section{Disclosure}

The authors have no disclosures to declare. Go to Neurology. org/ $\mathrm{N}$ for full disclosures.

\section{Appendix Authors}

\begin{tabular}{|c|c|c|}
\hline Name & Location & Contribution \\
\hline $\begin{array}{l}\text { Giuseppe } \\
\text { Liberatore, } \\
\text { MD }\end{array}$ & $\begin{array}{l}\text { Neuromuscular and } \\
\text { Neuroimmunology } \\
\text { Service, IRCCS Humanitas } \\
\text { Clinical and Research } \\
\text { Hospital, Rozzano (MI), } \\
\text { Italy }\end{array}$ & $\begin{array}{l}\text { Designed and } \\
\text { conceptualized study, } \\
\text { major role in acquisition of } \\
\text { data, analyzed the data, } \\
\text { drafted the manuscript for } \\
\text { intellectual content }\end{array}$ \\
\hline $\begin{array}{l}\text { Tiziana De } \\
\text { Santis, MD }\end{array}$ & $\begin{array}{l}\text { Department of Neurology, } \\
\text { IRCCS Humanitas Clinical } \\
\text { and Research Hospital, } \\
\text { Rozzano (MI), Italy }\end{array}$ & $\begin{array}{l}\text { Major role in the } \\
\text { acquisition of data, } \\
\text { revised the manuscript for } \\
\text { intellectual content }\end{array}$ \\
\hline $\begin{array}{l}\text { Pietro } \\
\text { Emiliano } \\
\text { Doneddu, MD }\end{array}$ & $\begin{array}{l}\text { Neuromuscular and } \\
\text { Neuroimmunology } \\
\text { Service, IRCCS Humanitas } \\
\text { Clinical and Research } \\
\text { Hospital, Rozzano (MI), } \\
\text { Italy }\end{array}$ & $\begin{array}{l}\text { Major role in the } \\
\text { acquisition of data, } \\
\text { revised the manuscript for } \\
\text { intellectual content }\end{array}$ \\
\hline $\begin{array}{l}\text { Francesco } \\
\text { Gentile, MD }\end{array}$ & $\begin{array}{l}\text { Neuromuscular and } \\
\text { Neuroimmunology } \\
\text { Service, IRCCS Humanitas } \\
\text { Clinical and Research } \\
\text { Hospital, Rozzano (MI), } \\
\text { Italy }\end{array}$ & $\begin{array}{l}\text { Analyzed data, revised the } \\
\text { manuscript for intellectual } \\
\text { content }\end{array}$ \\
\hline $\begin{array}{l}\text { Alberto } \\
\text { Albanese, } \\
\text { MD, PhD }\end{array}$ & $\begin{array}{l}\text { Department of Neurology, } \\
\text { IRCCS Humanitas Clinical } \\
\text { and Research Hospital, } \\
\text { Rozzano (MI); Department } \\
\text { of Neuroscience, Catholic } \\
\text { University of the Sacred } \\
\text { Heart, Milan, Italy }\end{array}$ & $\begin{array}{l}\text { Discussion of results, } \\
\text { revised the manuscript for } \\
\text { intellectual content }\end{array}$ \\
\hline
\end{tabular}


Appendix (continued)

\begin{tabular}{|c|c|c|}
\hline Name & Location & Contribution \\
\hline $\begin{array}{l}\text { Eduardo } \\
\text { Nobile } \\
\text { Orazio, MD, } \\
\text { PhD, FAAN }\end{array}$ & $\begin{array}{l}\text { Neuromuscular and } \\
\text { Neuroimmunology Service, } \\
\text { IRCCS Humanitas Clinical } \\
\text { and Research Hospital, } \\
\text { Rozzano (MI); Department } \\
\text { of Medical Biotechnology } \\
\text { and Translational Medicine, } \\
\text { Milan University, Milan, Italy }\end{array}$ & $\begin{array}{l}\text { Designed and } \\
\text { conceptualized study, } \\
\text { analyzed the data, revised } \\
\text { the manuscript for } \\
\text { intellectual content }\end{array}$ \\
\hline
\end{tabular}

\section{References}

1. Mao L, Wang M, Chen S, et al. Neurological manifestations of hospitalized patients with COVID-19 in Wuhan, China: a retrospective case series study. MedRxiv 2020; 2020:2020.
2. Zhao H, Shen D, Zhou H, Liu J, Chen S. Guillain-Barré syndrome associated with SARS-CoV-2 infection: causality or coincidence? Lancet Neurol 2020;19:383-384.

3. Toscano G, Palmerini F, Ravaglia S, et al. Guillain-Barré syndrome associated with SARS-CoV-2. N Engl J Med 2020;382:2574-2576.

4. Gutiérrez-Ortiz C, Méndez A, Rodrigo-Rey S, et al. Miller Fisher syndrome and polyneuritis cranialis in COVID-19. Neurology 2020;95:e601-e605.

5. Juliao Caamaño DS, Alonso Beato R. Facial diplegia, a possible atypical variant of Guillain-Barré syndrome as a rare neurological complication of SARS-CoV-2. J Clin Neurosci 2020;77:230-232.

6. Assini A, Benedetti L, Di Maio S, Schirinzi E, Del Sette M. New clinical manifestation of COVID-19 related Guillain-Barré syndrome highly responsive to intravenous immunoglobulins: two Italian cases. Neurol Sci 2020;41:1657-1658.

7. Sejvar JJ, Kohl KS, Gidudu J, et al. Guillain-Barré syndrome and Fisher syndrome: case definitions and guidelines for collection, analysis, and presentation of immunization safety data. Vaccine 2011;29:599-612.

8. Latronico N, Bolton CF. Critical illness polyneuropathy and myopathy: a major cause of muscle weakness and paralysis. Lancet Neurol 2011;10:931-941.

9. Uncini A, Kuwabara S. The electrodiagnosis of Guillain-Barré syndrome subtypes: where do we stand? Clin Neurophysiol 2018;129:2586-2593.

10. Nagashima T, Koga M, Odaka M, et al. Continuous spectrum of pharyngeal-cervicalbrachial variant of Guillain-Barré syndrome. Arch Neurol 2007;64:1519-1523.

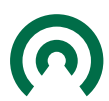

$\underset{\text { PoOCAST }}{\text { Neurology }}$

November 24, 2020

\section{Neural correlates of sign language production revealed by electrocorticography (see p. 953)}

In the first segment, Dr. Jason Crowell talks with Dr. Jennifer Shum about her paper on neural correlates of sign language production. Then, Dr. David Lapides speaks with Dr. Matthew Stuart Robbins on the Headache Quality Measurement Set.

Disclosures can be found at Neurology.org.

CME Opportunity: Listen to this week's Neurology Podcast and earn 0.5 AMA PRA Category $1 \mathrm{CME}$ Credits $^{\mathrm{TM}}$ by completing the online Podcast quiz.

\section{AAN Online Learning}

Browse a variety of online CME, self-assessment, and other learning activities to suit your wide-ranging interests and learning styles. Visit AAN.com/Learn. 


\section{Neurology}

\section{Clinical Reasoning: A case of COVID-19-associated pharyngeal-cervical-brachial variant of Guillain-Barré syndrome}

Giuseppe Liberatore, Tiziana De Santis, Pietro Emiliano Doneddu, et al. Neurology 2020;95;978-983 Published Online before print September 11, 2020 DOI 10.1212/WNL.0000000000010817

This information is current as of September 11, 2020

\section{Updated Information \&} Services

References

Subspecialty Collections

Permissions \& Licensing

Reprints including high resolution figures, can be found at: http://n.neurology.org/content/95/21/978.full

This article cites 10 articles, 1 of which you can access for free at: http://n.neurology.org/content/95/21/978.full\#ref-list-1

This article, along with others on similar topics, appears in the following collection(s):

\section{EMG}

http://n.neurology.org/cgi/collection/emg

Guillain-Barre syndrome

http://n.neurology.org/cgi/collection/guillainbarre_syndrome

Information about reproducing this article in parts (figures,tables) or in its entirety can be found online at:

http://www.neurology.org/about/about_the_journal\#permissions

Information about ordering reprints can be found online:

http://n.neurology.org/subscribers/advertise

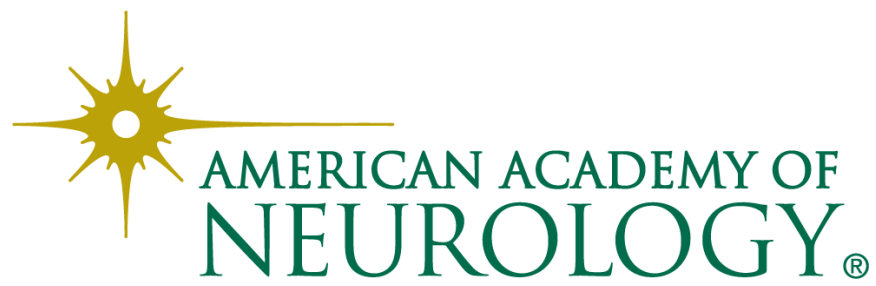

